\title{
Physiological and biochemical responses to drought stress in Barbados cherry
}

\section{David Barbosa Medeiros ${ }^{1 *}$, Elizamar Ciriaco da Silva², Hugo Rafael Bentzen Santos ${ }^{3}$, Cinthya Mirella Pacheco ${ }^{4}$, Rosimar dos Santos Musser ${ }^{1}$, Rejane Jurema Mansur Custódio Nogueira ${ }^{5}$}

\author{
1Departamento de Agronomia, Universidade Federal Rural de Pernambuco, Recife, PE, Brazil. \\ ${ }^{2}$ Departamento de Biologia, Centro de Ciências Biológicas e da Saúde, Universidade Federal de Sergipe, São \\ Cristóvão, SE, Brazil. \\ ${ }^{3}$ Departamento de Tecnologia Rural, Universidade Federal Rural de Pernambuco, Recife, PE, Brazil. \\ ${ }^{4}$ Departamento de Genética, Centro de Ciências Biológicas, Universidade Federal de Pernambuco, Recife, PE, Brazil. \\ ${ }^{5}$ Departamento de Biologia, Universidade Federal Rural de Pernambuco, Recife, PE, Brazil. \\ *Corresponding author: davidmedeiros3@hotmail.com \\ Received: 25 May 2012; Accepted: 3 September 2012
}

\begin{abstract}
To evaluate physiological genotypic differences between two Barbados cherry genotypes (13- and 14-CPA) under water deficit, initial growth, water relations, and organic solute accumulation were evaluated in an experiment performed using four-month-old seedlings, which were subjected to four water treatments $(100,75,50$, and $25 \%$ of field capacity), with five replications. Severe water deficit ( $25 \%$ of field capacity) negatively affected plant height, stem diameter, leaf area, dry matter of the leaves and stem to both genotypes, and root dry matter to genotype 13-CPA. Predawn $\left(\Psi_{\text {wod }}\right)$ and midday leaf water potentials $\left(\Psi_{\text {wmd }}\right)$ were reduced in plants grown under $25 \%$ of field capacity, only in the genotype 14-CPA. There was not a change in relative water content, even with the reduction in the leaf water potential. Severe water deficit did not induce organic solutes accumulation, instead it reduced carbohydrate content in leaves of genotypes and aminoacids, proline and proteins, in genotype 13-CPA. In the roots accumulation of all organic solutes studied, it was verified genotype 13-CPA under $25 \%$ of field capacity, but only carbohydrates increased in plants under $25 \%$ of field capacity to 14-CPA. These results suggest two different mechanisms used by Barbados cherry genotypes to maintain the water status. To the 13-CPA one, the accumulation of soluble organic solutes in the roots is the main mechanism used to maintain the tissue hydration. However, the 14-CPA genotype changed the root to shoot ratio in order to avoid desiccation. Despite the mechanism used by both genotypes, a moderate drought stress does not induce significant morphophysiological changes in Barbados cherry.
\end{abstract}

Keywords: Malpighia emarginata DC, soluble organic solutes, biomass allocation, water relations, water deficit. 


\section{INTRODUCTION}

Barbados cherry (Malpighia emarginata DC) is a crop with great economic potential in Brazil due to its high nutritional value. Its fruit has a high concentration of ascorbic acid (AA), which makes it an important species in regions with low-income populations. The wide acceptance of its fruit in foreign markets has led to its exportation as a fresh and processed product.

Several environmental factors limit the production of this crop, including the rainfall shortage, since water affects plant growth and development. During drought season, the inflow of water diminishes due the soil drying, which consequently affects all the growth processes dependent on turgor pressure, such as cell elongation and division (Larcher, 2006).

To evaluate plant water status, the leaf water potential $\left(\Psi_{w}\right)$ and relative water content (RWC) are essential parameters generally used to study plant physiological responses to drought stress (Silva et al., 2009b; Marchese et al., 2010; Silva et al., 2010). Silva et al. (2009b) stated that these parameters decrease in most plants under water deficit.

Among the various mechanisms used by plants to reduce the negative effects of water stress, many plant species accumulate soluble organic compounds, such as osmoregulators. This process is known as osmotic adjustment and it is considered as an important tolerancemechanism, which allows the maintenance of cellular turgor and favors the absorption of water (White et al., 2000; Chaves et al., 2003). In this process, the biosynthesis and accumulation of nontoxic molecules of low-molecular weight in the vacuole and cytosol, such as inorganic ions, soluble sugars, aminoacids, proline, glycine-betaine, among others, contribute to keep the integrity of cellular membranes and proteins, which are necessary for metabolic activities. Therefore, studies on the accumulation of these molecules have been used as physiological indicators in the evaluation of drought tolerance in several species (Shao et al., 2006; Farooq et al., 2009).

The different physiological mechanisms used by different plant species to tolerate drought are also found within one species or among genotypes, varieties, or cultivars. In this context, studies have been done aiming at comprehending how some species or cultivars support drought periods and how the physiological and metabolic processes modulate this tolerance in several species, such as Barbados cherry (Nogueira et al., 2001), citrus (Peixoto et al., 2006; Al-Absi, 2009; Nascimento et al., 2010), umbu tree (Silva et al., 2009a, b), grape (Toumi et al., 2008; Santesteban et al., 2009), wheat (Shao et al., 2006), and a number of others.

These authors have found intraspecific differences in drought tolerance evidencing different responses under water stresses as a result of a cascade in physiological and biochemical events, which culminate in changes on growth patterns. As observed by Peixoto et al. (2006), changes on growth parameters (leaf area ratio - LAR, relative growth rate, and net assimilation rate) in citrus genotypes support that short periods of drought help to maintain a positive balance of photosynthesis and dry mass production. Specifically in Barbados cherry, some physiological changes in gas exchange and water relations were observed after 20 days of watering disruption, with the restriction on transpiration rate by a strictly increase in stomatal resistance and decrease in $\Psi_{w}$ and RWC (Nogueira et al., 2001). Intraspecific differences were also observed in umbu tree genotypes during intermittent drought, which present an isohydric behavior, but it has a great variability in the production of organic solutes between genotypes (Silva et al., 2009b).

The Universidade Federal Rural de Pernambuco has cultivated an Active Germplasm Bank of Barbados cherry (BAG Acerola - UFRPE) since 1998, located in Carpina City, North Forest Zone of Pernambuco State, Brazil, which is currently composed of 42 genotypes. The annual rainfall and temperature mean in this region are $1,702.1 \mathrm{~mm}$ and $25^{\circ} \mathrm{C}$, respectively (Mascarenhas et al., 2005). However, there are large areas subject to drought during the year, and to increase the area under cultivation by this crop is so important that requires knowledge of the physiological responses to drought, especially during the initial phase of development, this being the most critical in establishing any culture.

Therefore, the aims of this work were: to evaluate two Barbados cherry genotypes under water deficit in order to verify if there are physiological differences between them relative to initial growth, water relations, and organic solute accumulation, since there is no information about them; and to test the hypothesis that Barbados cherry tolerate drought through the maintenance of water status by reducing its leaf water potential, due to the accumulation of osmoregulators that help to maintain the growth processes.

\section{MATERIAL AND METHODS}

Plant material and growth conditions: The experiment was carried out in a greenhouse from January 
to May, in 2009. The average daily temperature and relative air humidity varied from 24.3 to $31^{\circ} \mathrm{C}$ and from 50.2 to $75.0 \%$, respectively.

The plant material was selected considering the high productivity, high AA content, and some different aspects such as tree canopy and height, 13-CPA being tall and 14-CPA being short (Musser et al., 2005). According to Musser et al. (2005), the annual production in 2000 was 32.2 and $44.7 \mathrm{~kg} \mathrm{~kg}$ plant- 1 and $A A$ of 2,068.5 and $1,686.2 \mathrm{mg} A \mathrm{~A}$ for each $100 \mathrm{~mL}$ of pulp, respectively.

The seedlings were propagated by cutting and transferred 60 days later to polyethylene pots containing $8 \mathrm{~kg}$ of soil. The soil properties are presented in Table 1. Thirty days after the transfer (acclimatization period), water treatments $(100,75,50$ and $25 \%$ of field capacity FC) were applied in the basis of FC.

The FC was determined by the gravimetric method following the methodology described by Souza et al. (2000), which consists on the difference between the wet soil after saturation and free drainage, and the weight of the dry soil. Maintenance of the water treatments was made by daily weighing of the pots replacing the water lost by transpiration using a precision scale, up to $15 \mathrm{~kg}$ of capacity.

Growth measurements: Plant height, number of leaves, and stem diameter were weekly measured after starting the water treatments. At the end of the experimental period, the plants were harvested and the organs were separated (leaves, stem, and roots). LA was determined following the methodology described by Mielke et al. (1995) by weighing leaf discs. Six of them were detached from basal, median, and apical leaves. Using the known area of the detached leaf discs, their dry matter and total dry matter of the leaves, total LA was estimated. Leaves (LDM), stem (SDM), roots (RDM), and total (TDM) dry matter were also determined after drying the material in an oven $\left(65^{\circ} \mathrm{C}\right)$ until constant weight. From the values of dry matter and $L A$, $L A$ ratio (LAR), biomass allocation to leaves (BAL), stem (BAS) and roots (BAR), and root to shoot ratio were calculated according to Benincasa (2003).

Water potential and relative water content measurements: $\Psi_{w}$ and RWC were determined at predawn $\left(\Psi_{\text {wpd }}\right)$ and at midday $\left(\Psi_{\text {wmd }}\right), 90$ days after the beginning of the water treatment. The $\Psi_{w}$ was measured using a pressure chamber (model 3035, Soil Moisture Equipment Corp, CA, USA) in branches containing two pairs of leaves, located in the middle portion of the plants, following the model described by Scholander et al. (1964).
Table 1. Soil chemical and physical characteristics. The soil was collected in a deep of 0 to $20 \mathrm{~cm}$ from the Estação Experimental de Cana-de-Açúcar do Carpina in Carpina City, North Forest Zone of Pernambuco State, Brazil.

\begin{tabular}{|c|c|}
\hline Analysis & Soil depth $0-20 \mathrm{~cm}$ \\
\hline \multicolumn{2}{|c|}{ Chemical } \\
\hline Electrical conductivity & $0.83 \mathrm{dS} \mathrm{m}^{-1}$ \\
\hline $\mathrm{pH}$ & 4.0 \\
\hline $\mathrm{Ca}^{2+}$ & $0.81 \mathrm{cmolc} \mathrm{kg}^{-1}$ \\
\hline $\mathrm{Mg}^{2+}$ & $0.41 \mathrm{cmolc} \mathrm{kg}^{-1}$ \\
\hline $\mathrm{Na}^{+}$ & $0.32 \mathrm{cmolc} \mathrm{kg}^{-1}$ \\
\hline $\mathrm{N}$ & $1.80 \mathrm{~g} \mathrm{~kg}^{-1}$ \\
\hline $\mathrm{P}$ & $41 \mathrm{mg} \mathrm{kg}^{-1}$ \\
\hline $\mathrm{K}^{+}$ & $0.06 \mathrm{cmolc} \mathrm{kg}^{-1}$ \\
\hline $\mathrm{Al}^{3+}$ & $3.10 \mathrm{cmolc} \mathrm{kg}^{-1}$ \\
\hline Organic matter & $38.27 \mathrm{~g} \mathrm{~kg}^{-1}$ \\
\hline \multicolumn{2}{|c|}{ Physical } \\
\hline Total porosity & $45.0 \%$ \\
\hline Bulk density & $1.42 \mathrm{~g} \mathrm{~cm}^{-3}$ \\
\hline Real density & $2.58 \mathrm{~g} \mathrm{~cm}^{-3}$ \\
\hline Sand & $69.1 \%$ \\
\hline Silt & $10.4 \%$ \\
\hline Clay & $20.5 \%$ \\
\hline Textural classification & Franco sandy clay \\
\hline \multicolumn{2}{|c|}{ Moisture retention curve } \\
\hline Moisture at $1.5 \mathrm{MPa}$ & $14.0 \%$ \\
\hline Moisture at $0.03 \mathrm{MPa}$ & $18.9 \%$ \\
\hline Useful water & $4.9 \%$ \\
\hline
\end{tabular}

RWC was determined in the same leaves used for $\Psi_{\text {w }}$ measurements using six discs of each leaf, which were weighed to obtain fresh mass weight (FMW). Then, the discs were placed in Petri dishes containing filter paper with $10 \mathrm{~mL}$ of deionized water. The dishes were kept in a refrigerator for a period of 24 hours and afterwards they were weighed again to obtain the turgid mass weight (TMW). Finally, the discs were placed in an oven at $65^{\circ} \mathrm{C}$ until they reached constant weight, thus obtaining the dry mass weight (DMW). According to Cairo (1995), RWC was calculated using the following formula: $R W C=\{[(F M W-D M W) /(T M W-D M W)] \times 100 \%\}$.

Soluble carbohydrate, free aminoacids, free proline, and soluble proteins contents: At the end of the experimental period, samples of leaves and roots were collected to perform biochemical analysis. About $1 \mathrm{~g}$ of fresh tissue was taken and frozen to $-10^{\circ} \mathrm{C}$. The extracts were prepared by grinding the material with 5 (leaves) or $4 \mathrm{~mL}$ (roots) of $0.1 \mathrm{M}$ monobasic phosphate buffer. The homogenized extracts were filtered in nylon tissue and centrifuged in a cold centrifuge $3,000 g_{n}$ for $15 \mathrm{~min}$ and the supernatant was used for the analysis. Soluble carbohydrates were determined by the phenol-sulfuric acid method, using $D(+)$-glucose as standard (Dubois 
et al., 1956). Free aminoacids were analyzed by the ninhydrin method using L-leucine as the standard (Yemm and Cocking, 1955). Free proline content was determined by both the ninhydrin and the phosphoric acid methods, using proline as standard (Bates, 1973). The soluble protein determination was performed by the protein-dye binding method using bovine serum albumin as standard (Bradford, 1976). All procedures were carried out using the colorimetric technique and a spectrophotometer, BIOSpectro, model SP220. The wave lengths used for total soluble carbohydrates, free proline, free aminoacid and soluble protein were 490, 520, 570 and $595 \mathrm{~nm}$, respectively.

Experimental design and statistical analysis: A completely random design was used in a factorial arrangement $2 \times 4$ corresponding to two genotypes (13-CPA and 14-CPA) and four water treatments (100, 75 , 50 , and $25 \%$ of FC) with five replications. Each replicate was composed of one plant per pot of each genotype, totaling 40 experimental parcels.

Data were submitted for analysis of variance (ANOVA), and the averages using. Tukey's multiple range test $(p<0.05)$ with the help of the ASSISTAT 7.5 software.

\section{RESULTS}

Growth: The extension and severity of the water deficit $(p<0.05)$ significantly affected almost all growth parameters in Barbados cherry genotypes (Figure 1, Tables 2 and 3). Reduction in stem diameter had been observed firstly to genotype 13-CPA and then to 14-CPA. This reduction was about $22.7 \%$ in plants under $25 \%$ of $\mathrm{FC}$ in comparison with control plants to genotype 13-CPA after 42 days of water treatment. After 91 days, this reduction was $21 \%$, with an average of $6.1 \mathrm{~mm}$. For genotype 14-CPA, similar values of stem diameter were verified among the treatments until 77 days, when reductions started to be observed in plants under $25 \%$ of FC, and continuing until 91 days, with a total decrease of $10.9 \%$ when compared with control plants (Figure 1).

The Barbados cherry displayed similar growth in both genotypes in relation to the plant height of the control ones, and those cultivated at $75 \%$ and $50 \%$ of FC. Although final plant height was similar (ca. $440 \mathrm{~mm}$ ) for both genotypes under control, 75 and $50 \%$ of $\mathrm{FC}$, the development differed between the two along the experimental period according to treatment (Figure 1). Both reacted positively to lower water availability. After 42 days, 13-CPA showed increased height under $50 \%$ of FC compared to control and $75 \%$ of FC. However, 14-CPA (shorter genotype) presented better height values under 50 and $75 \%$ of FC than control throughout all the experiment.

After a 28-day period in 13-CPA and 21 days in 14-CPA, significant reductions were observed in response to severe water deficit. At the end of the experimental period (91 days), these reductions were about 33.8 and $23.0 \%$, respectively.

Severe water stress significantly reduced the LA (Table 2). For 13-CPA, the reductions observed were 38.2 and $57.4 \%$ in 14-CPA for plants cultivated under $25 \%$ FC when compared with the Control ones.

LAR was not affected by water treatments applied (Table 2), and there was no difference among genotypes either. Thus, genotypes 13-CPA and 14-CPA used about $3,231.2 \mathrm{~mm}^{2}$ of their leaf surface to produce $1 \mathrm{~g}$ of dry matter $\left(\mathrm{mm}^{2} \mathrm{~g}^{-1} \mathrm{DM}\right)$.

The production of dry matter was significantly reduced by water stress in both genotypes (Table 3 ), with the exception to the RDM in 14-CPA, which was not affected by water deficit. Genotype 13-CPA showed RDM reduction of about $54 \%$ in plants grown under $25 \%$ of FC. In the leaves and stem, the stress applied induced reductions of 61.4 and $46.9 \%$ in $14-\mathrm{CPA}$, and 42.3 and $40.0 \%$ in 13-CPA, respectively. These results represent a large reduction of the TDM in plants under severe stress $(25 \%$ of FC), corresponding to 46.3 and $45.2 \%$ in genotypes 13-CPA and 14-CPA, respectively.

When evaluating the biomass allocation (Figure 2), similar behavior was observed in both genotypes, since the shoot had a higher biomass allocation than the roots in all water treatments. Nevertheless, water deficit induced a decrease in biomass allocation to roots in 13CPA in plants under $50 \%$ of $\mathrm{FC}$, and an increase in 14-CPA in plants under $25 \%$ of $\mathrm{FC}$.

Confirming the data on biomass allocation, the genotypes presented different physiological behavior to root to shoot ratio, as observed in Figure 2 . $13-\mathrm{CPA}$ reduced this ratio in stressed plants, while $14-\mathrm{CPA}$ increased in plants under severe stress ( $25 \%$ of $\mathrm{FC})$.

Water potential and relative water content: The genotypes presented differences relative to water relations. The most severe treatment ( $25 \%$ of FC) induced significant reductions in water potential at predawn $\left(\Psi_{\text {wpd }}\right)$ and midday $\left(\Psi_{\text {wmd }}\right)$ in 14-CPA when compared 


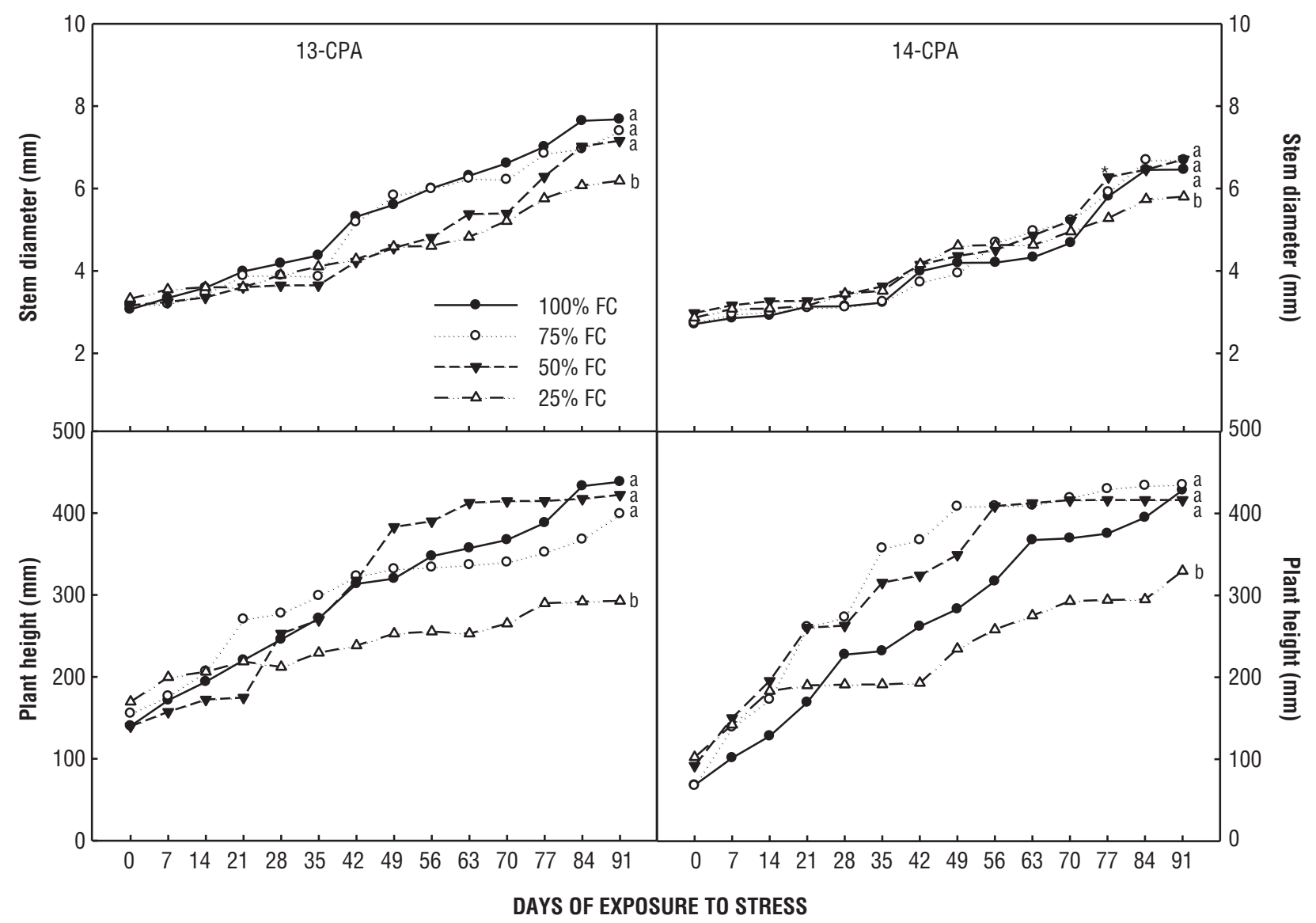

Figure 1. Stem diameter and plant height in two genotypes of Barbados cherry cultivated under four water treatments in greenhouse conditions. Lower case equal letters among treatments do not differ by Tukey's test $(\mathrm{p}<0.05)$. FC: field capacity.

Table 2. Leaf area and leaf area ratio in two Barbados cherry genotypes cultivated under four water treatments in greenhouse conditions.

\begin{tabular}{ccccc}
\hline Water & \multicolumn{2}{c}{ Leaf area $\left.\mathbf{( m m}^{2}\right)$} & \multicolumn{2}{c}{ Leaf area ratio $\left.\mathbf{( m m}^{\mathbf{2}} \mathbf{~ D D M}^{-1}\right)$} \\
\cline { 2 - 5 } treatments & 13-CPA & 14-CPA & 13-CPA & 14-CPA \\
\hline $100 \%$ of FC & $43,662.5 \mathrm{aA}$ & $43,859.8 \mathrm{aA}$ & $2,885.6 \mathrm{aA}$ & $3,608.7 \mathrm{aA}$ \\
$75 \%$ of FC & $55,659.6 \mathrm{aA}$ & $40,441.0 \mathrm{aB}$ & $3,775.2 \mathrm{aA}$ & $3,343.7 \mathrm{aA}$ \\
$50 \%$ of FC & $44,359.4 \mathrm{aA}$ & $34,855.4 \mathrm{aA}$ & $3,327.2 \mathrm{aA}$ & $2,825.3 \mathrm{aA}$ \\
$25 \%$ of FC & $27,096.5 \mathrm{bA}$ & $18,683.2 \mathrm{bA}$ & $3,376.5 \mathrm{aA}$ & $2,707.1 \mathrm{aA}$ \\
\hline
\end{tabular}

FC: field capacity. Equal letters, lower case among treatments and upper case between genotypes do not significantly differ by Tukey's test ( $p<0.05)$.

with control plants (Figure 3). $\Psi_{\text {wpd }}$ was reduced $33.3 \%$ in stressed plants with values of $-1.56 \mathrm{MPa}$. At noon, the reduction was about $36.9 \%$, with values of $-2.5 \mathrm{MPa}$. Nevertheless, these reductions were not observed among treatments to genotype 13-CPA.

RWC did not significantly differ $(p<0.05)$ among water treatments nor between genotypes. The average values found in predawn RWC ranged from 76.1 to $93.3 \%$, and at noon they ranged from 75.0 to $92.9 \%$ (Figure 4).

Soluble carbohydrate, free aminoacids, free proline, and soluble proteins contents: In general, the content of organic compounds was affected by severe water deficit in the leaves (Table 4) and roots (Table 5). Soluble carbohydrates were reduced in the leaves of plants 
Table 3. Leaves, stem, roots, and total dry matter production in two Barbados cherry genotypes cultivated under four water treatments in greenhouse conditions.

\begin{tabular}{|c|c|c|c|c|}
\hline \multirow{2}{*}{ Water treatments } & \multicolumn{2}{|c|}{$\operatorname{LDM}(\mathrm{g})$} & \multicolumn{2}{|c|}{ SDM (g) } \\
\hline & 13-СРA & 14-СРA & 13-СРA & 14-СРA \\
\hline $100 \%$ of $\mathrm{FC}$ & $2.6 \mathrm{aA}$ & $2.7 \mathrm{aA}$ & $6.5 \mathrm{aA}$ & $6.4 \mathrm{aA}$ \\
\hline $75 \%$ of $\mathrm{FC}$ & $2.9 \mathrm{aA}$ & $2.6 \mathrm{aA}$ & $6.1 \mathrm{aA}$ & $6.2 \mathrm{aA}$ \\
\hline $50 \%$ of $\mathrm{FC}$ & $2.5 \mathrm{aA}$ & $2.3 \mathrm{aA}$ & $6.8 \mathrm{aA}$ & $6.8 \mathrm{aA}$ \\
\hline $25 \%$ of $\mathrm{FC}$ & $1.5 \mathrm{bA}$ & $1.0 \mathrm{bA}$ & $3.9 \mathrm{bA}$ & $3.4 \mathrm{bA}$ \\
\hline \multirow{2}{*}{ Water treatments } & \multicolumn{2}{|c|}{ RDM (g) } & \multicolumn{2}{|c|}{ TDM (g) } \\
\hline & 13-СРA & 14-CPA & 13-СРA & 14-СРА \\
\hline $100 \%$ of $\mathrm{FC}$ & $5.9 \mathrm{aA}$ & $3.4 \mathrm{aB}$ & $15.1 \mathrm{aA}$ & $12.5 \mathrm{aB}$ \\
\hline $75 \%$ of $\mathrm{FC}$ & $5.7 \mathrm{aA}$ & $3.3 \mathrm{aB}$ & $14.7 \mathrm{aA}$ & $12.0 \mathrm{aB}$ \\
\hline $50 \%$ of $\mathrm{FC}$ & $4.0 \mathrm{bA}$ & $3.3 \mathrm{aA}$ & $13.3 \mathrm{aA}$ & $12.5 \mathrm{aA}$ \\
\hline $25 \%$ of $\mathrm{FC}$ & $2.7 \mathrm{cA}$ & $2.4 \mathrm{aA}$ & $8.1 \mathrm{bA}$ & $6.9 \mathrm{bA}$ \\
\hline
\end{tabular}

LDM: leaves dry matter; SDM: stem dry matter; RDM: roots dry matter; TDM: total dry matter; FC: field capacity.Equal letters, lower case among treatments and upper case between genotypes do not significantly differ by Tukey's test $(p<0.05)$.

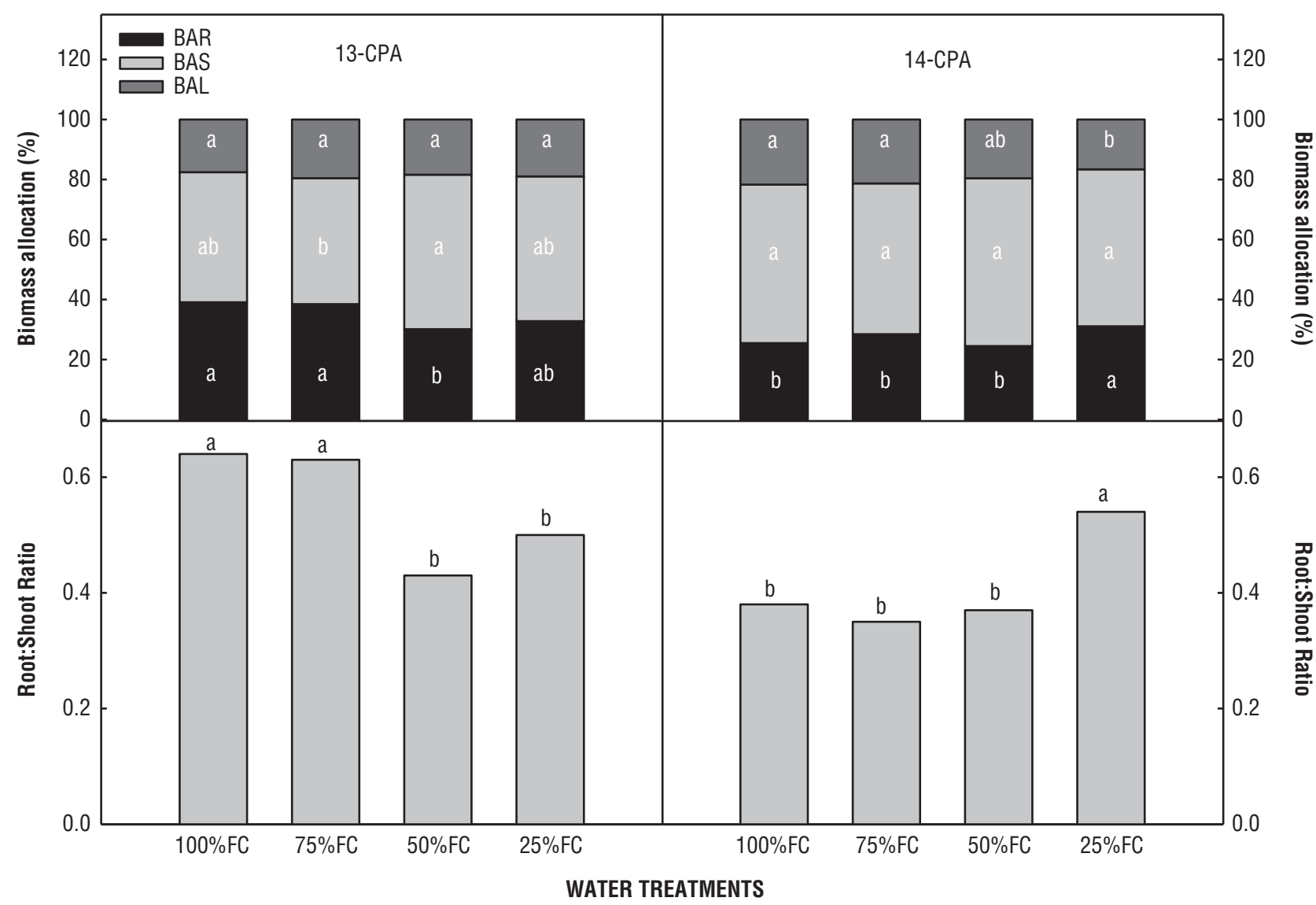

Figure 2. Biomass allocation to roots (BAR), stem (BAS), and leaves (BAL) and root to shoot ratio in two genotypes of Barbados cherry cultivated under four water treatments in greenhouse conditions. Lower case equal letters among treatments do not differ by Tukey's test $(p<0.05)$. FC: field capacity.

under $25 \%$ of $\mathrm{FC}$ in comparison with the other treatments by about 51.8 and $38.4 \%$ to genotypes 13-CPA and 14-CPA, respectively. Free aminoacids were reduced
$46.3 \%$ in $13-\mathrm{CPA}$ ( $25 \%$ of $\mathrm{FC}$ ), but they did not differ significantly in 14-CPA $(p<0.05)$ between treatments $(100$ and $25 \%$ of FC). However, there was a difference between 


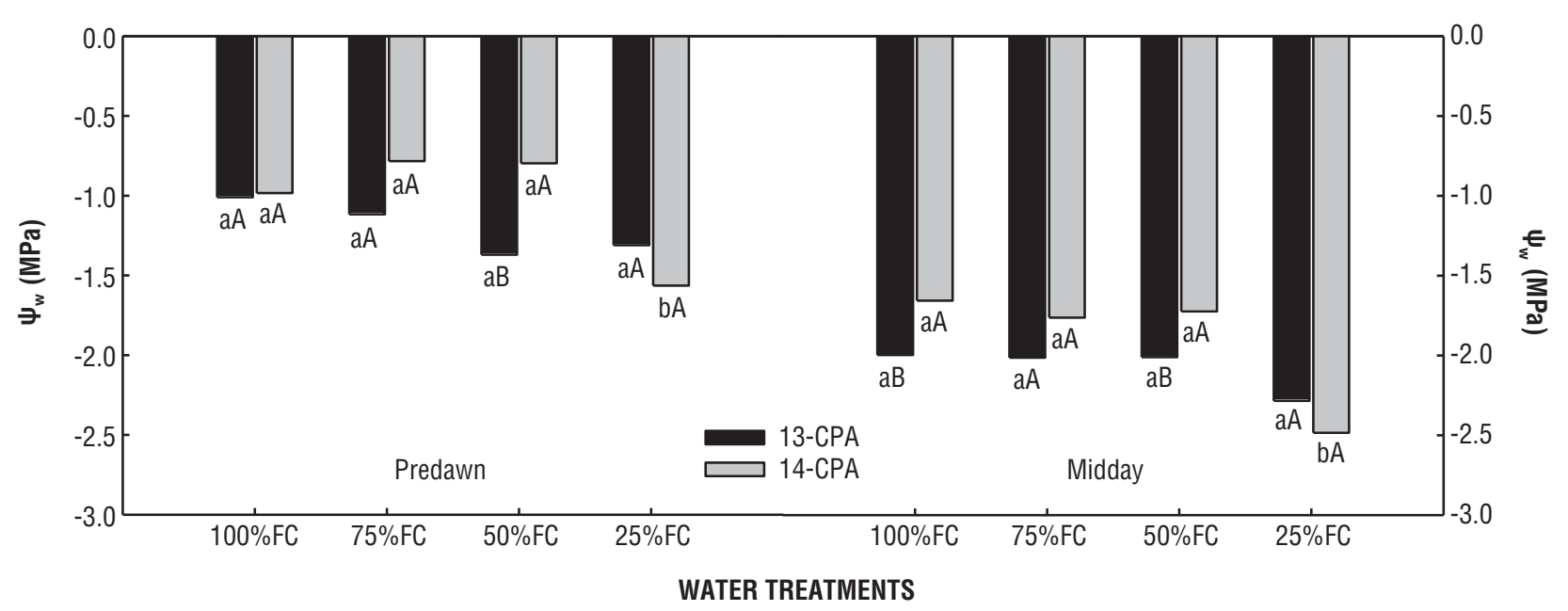

Figure 3. Water potential $\left(\Psi_{\mathrm{w}}\right)$ in two genotypes of Barbados cherry cultivated with four water treatments in greenhouse conditions. Equal letters, lower case among treatments and upper case between genotypes do not significantly differ by Tukey's test $(p<0.05)$. FC: field capacity.

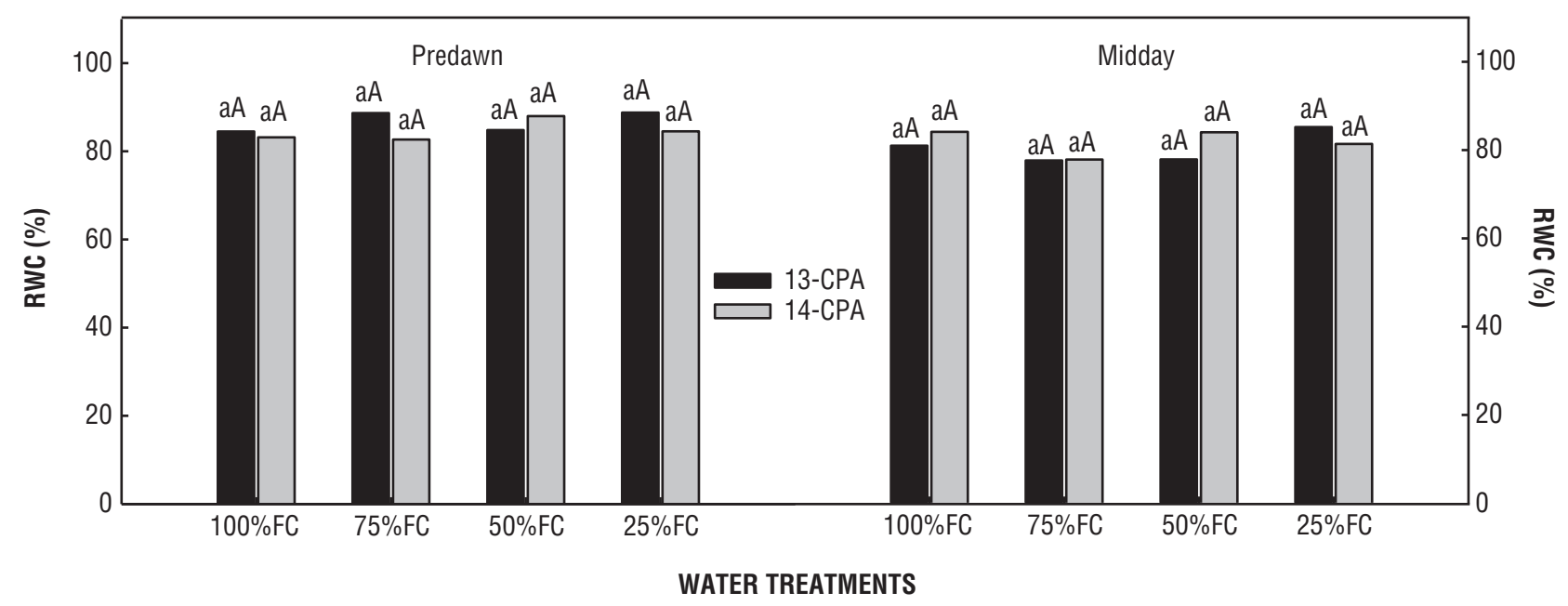

Figure 4. Relative water content (RWC) in two Barbados cherry genotypes cultivated with four water treatments in greenhouse conditions. Equal letters, lower case among treatments and upper case between genotypes do not significantly differ by Tukey's test ( $\mathrm{p}<0.05)$. FC: field capacity.

$25 \%$ of $\mathrm{FC}$ treatment and the 75 and 50 of $\mathrm{FC}$, which

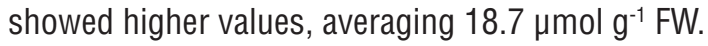

Free proline in the leaves was also reduced in plants under $25 \%$ FC in genotype 13-CPA (55.6\%). However, there were no differences among treatments to genotype 14-CPA. The same behavior occurred with soluble protein. Genotype 13-CPA reduced protein content by about $55.23 \%$ in plants grown under $25 \%$ of FC in comparison with the other treatments. However, 14-CPA showed a tendency to increase the protein content in stressed plants. The test to compare the averages showed that the treatment of moderate stress (50\% of FC) increased the protein in $50.03 \%$ when compared to the control plants.
In the roots (Table 5), the pattern of soluble solutes accumulation was not the same as in the leaves. Increase of $40.3 \%$ in carbohydrate content was verified in plants under $25 \%$ of FC to $13-\mathrm{CPA}$ and $30.7 \%$ to $14-\mathrm{CPA}$. Free aminoacids differed only in 13-CPA, increasing $25 \%$ of FC pronouncedly to treatment by about $67.3 \%$ (average of $16.62 \mu \mathrm{mol} \mathrm{g}^{-1} \mathrm{FW}$ ) when compared with $100 \%$ of FC.

In relation to free proline in the roots, increases were verified in all stress treatments of the genotype 13-CPA. Plants under $75 \%$ presented an increase of $36.4 \%$ in free proline, while plants of genotype 14-CPA did not show significant differences between water treatments. The average proline values of 14-CPA were $0.14 \mu \mathrm{mol} \mathrm{g}^{-1} \mathrm{FW}$. 
Table 4. Soluble carbohydrate, free aminoacids, free proline and soluble proteins contents in leaves of two Barbados cherry genotypes cultivated under four water treatments in greenhouse conditions.

\begin{tabular}{|c|c|c|c|c|}
\hline \multirow{2}{*}{ Water treatments } & \multicolumn{2}{|c|}{ Carbohydrate $\left(\mu \mathrm{mol} \mathrm{g} \mathrm{g}^{-1} \mathrm{FM}\right)$} & \multicolumn{2}{|c|}{ Aminoacids ( $\left.\mu \mathrm{mol} \mathrm{g} \mathrm{g}^{-1} \mathrm{FM}\right)$} \\
\hline & 13-СРA & 14-СРA & 13-СРA & 14-СРA \\
\hline $100 \%$ of $\mathrm{FC}$ & $93.90 \mathrm{aA}$ & $83.92 \mathrm{aA}$ & $10.34 \mathrm{aA}$ & $10.48 \mathrm{bA}$ \\
\hline $75 \%$ of FC & $96.71 \mathrm{aB}$ & $126.36 \mathrm{aA}$ & $12.22 \mathrm{aB}$ & $21.01 \mathrm{aA}$ \\
\hline $50 \%$ of $\mathrm{FC}$ & $96.31 \mathrm{aA}$ & $118.75 \mathrm{aA}$ & $11.26 \mathrm{aB}$ & $16.38 \mathrm{aA}$ \\
\hline $25 \%$ of $\mathrm{FC}$ & $45.21 \mathrm{bA}$ & $67.51 \mathrm{bA}$ & $6.09 \mathrm{bA}$ & $5.65 \mathrm{bA}$ \\
\hline \multirow{2}{*}{ Water treatments } & \multicolumn{2}{|c|}{ Proline $\left(\mu \mathrm{mol} \mathrm{g} \mathrm{g}^{-1} \mathrm{FM}\right)$} & \multicolumn{2}{|c|}{ Proteins $\left(\mu \mathrm{mol} \mathrm{g} \mathrm{g}^{-1} \mathrm{FM}\right)$} \\
\hline & 13-СРA & 14-СРA & 13-CPA & 14-СРA \\
\hline $100 \%$ of $\mathrm{FC}$ & $0.18 \mathrm{aA}$ & $0.10 \mathrm{aA}$ & $1,110.03 \mathrm{bA}$ & $1,076.2 \mathrm{bA}$ \\
\hline $75 \%$ of FC & $0.16 \mathrm{aA}$ & $0.12 \mathrm{aA}$ & $2,170.41 \mathrm{aA}$ & $1,175.7 \mathrm{bB}$ \\
\hline $50 \%$ of $\mathrm{FC}$ & $0.20 \mathrm{aA}$ & $0.19 \mathrm{aA}$ & $1,532.64 \mathrm{bB}$ & $2,253.3 \mathrm{aA}$ \\
\hline $25 \%$ of $\mathrm{FC}$ & $0.08 \mathrm{bA}$ & $0.14 \mathrm{aA}$ & $661.49 \mathrm{cB}$ & $1573.3 \mathrm{bA}$ \\
\hline
\end{tabular}

FC: field capacity. Equal letters, lower case among treatments and upper case between genotypes do not significantly differ by Tukey's test $(p<0.05)$.

Table 5. Soluble carbohydrate, free aminoacids, free proline and soluble protein contents in roots of two Barbados cherry genotypes cultivated under four water treatments in greenhouse conditions.

\begin{tabular}{|c|c|c|c|c|}
\hline \multirow{2}{*}{ Water treatments } & \multicolumn{2}{|c|}{ Carbohydrate $\left(\mu \mathrm{mol} \mathrm{g}{ }^{-1} \mathrm{FM}\right)$} & \multicolumn{2}{|c|}{ Aminoacids $\left(\mu \mathrm{mol} \mathrm{g}^{-1} \mathrm{FM}\right)$} \\
\hline & 13-СРA & 14-СРA & 13-СРA & 14-CPA \\
\hline $100 \%$ of $\mathrm{FC}$ & $84.62 \mathrm{bA}$ & $73.12 \mathrm{bA}$ & $5.44 \mathrm{cB}$ & $7.52 \mathrm{aA}$ \\
\hline $75 \%$ of $\mathrm{FC}$ & $78.96 \mathrm{bA}$ & $85.84 \mathrm{abA}$ & $10.49 \mathrm{bA}$ & $6.86 \mathrm{aB}$ \\
\hline $50 \%$ of $F C$ & $66.69 \mathrm{bB}$ & $91.17 \mathrm{abA}$ & $9.53 \mathrm{bA}$ & $8.98 \mathrm{aA}$ \\
\hline $25 \%$ of $\mathrm{FC}$ & $128.37 \mathrm{aA}$ & $105.47 \mathrm{aB}$ & $16.62 \mathrm{aA}$ & $7.96 \mathrm{aB}$ \\
\hline \multirow{2}{*}{ Water treatments } & \multicolumn{2}{|c|}{ Proline $\left(\mu \mathrm{mol} \mathrm{g} \mathrm{g}^{-1} \mathrm{FM}\right)$} & \multicolumn{2}{|c|}{ Proteins $\left(\mu \mathrm{mol} \mathrm{g} \mathrm{g}^{-1} \mathrm{FM}\right)$} \\
\hline & 13-СРA & 14-СРA & 13-СРА & 14-СРA \\
\hline $100 \%$ of $\mathrm{FC}$ & $0.07 \mathrm{bB}$ & $0.15 \mathrm{aA}$ & $1,972.4 \mathrm{bB}$ & $3,649.34 \mathrm{aA}$ \\
\hline $75 \%$ of $\mathrm{FC}$ & $0.12 \mathrm{aA}$ & $0.13 \mathrm{aA}$ & $2,573.36 \mathrm{bB}$ & $3,820.39 \mathrm{aA}$ \\
\hline $50 \%$ of $\mathrm{FC}$ & $0.10 \mathrm{aB}$ & $0.13 \mathrm{aA}$ & $1,960.36$ bB & $3,460.39 \mathrm{aA}$ \\
\hline $25 \%$ of $\mathrm{FC}$ & $0.10 \mathrm{aB}$ & $0.14 \mathrm{aA}$ & $5,179.16 \mathrm{aA}$ & $3,257.42 \mathrm{aB}$ \\
\hline
\end{tabular}

FC: field capacity. Equal letters, lower case among treatments and upper case between genotypes do not significantly differ by Tukey's test ( $p<0.05)$.

Protein content also increased in plants under $25 \%$ of FC $(58.13 \%)$ in genotype 13-CPA. However, no significant differences were observed among treatments to 14-CPA, which presented average values of $3,546.88 \mu \mathrm{mol} \mathrm{g}^{-1} \mathrm{FW}$.

\section{DISCUSSION}

It is well-known that water deficits generally affect plant growth and development negatively. When water deficit develops gradually, a sequence of physiological and biochemical events will occur. The first and most sensitive response to water deficit in plants is the reduction in growth processes due to loss of cell turgor (Larcher, 2006). In this research, both genotypes presented similar growth in height, stem diameter, and LA during the experimental period, regardless of whether they were cultivated at 100,
75 , and $50 \%$ of FC. This demonstrates that neither mild nor moderate stress causes significant growth alteration.

The reductions in growth parameters observed in these studies to plants grown with $25 \%$ of FC seem to be associated with decreases in cell turgor, and the taller genotype 13-CPA was affected earlier than 14-CPA, considered the shorter genotype. The reduction observed in plants grown under $25 \%$ of FC must be explained due to the lower turgor pressure caused by the low-soil water availability, which involves processes such as cell division and elongation (Shao et al., 2008; Al-Absi, 2009). Thus, plants tend to be smaller in height, LA, stem diameter, and all growth processes dependent on turgor. This fact was observed in the present study with Barbados cherry genotypes only between plants grown under severe stress ( $25 \%$ of $\mathrm{FC}$ ). However, these plants have no paralyzed growth during the experimental period and for almost all parameters, plants under mild ( $75 \%$ of FC) and moderate 
( $50 \%$ of $\mathrm{FC})$ stresses did not significantly differ from the Control ones. These results demonstrate a certain degree of drought tolerance in the Barbados cherry.

Several authors have found similar results, verifying reductions in plant growth with the severity or extent of the water stress. Examples include citrus genotypes cultivated with $25 \%$ of FC (Nascimento et al., 2010) and rootstock of citrus submitted to 16 days without water (Donato et al., 2007). In addition, Al-Absi (2009) verified reductions in plant height of other citrus cultivated at less than $50 \%$ of FC.

The same results were observed with LA, plants under $25 \%$ of $F C$ reduced it in both genotypes. However, LAR was not affected by water deficit. This result suggests that dry matter reduced at the same proportion as LA's reduction, once LAR is the ratio between LA and TDM. In many situations, the reduction in LA occurs due to the reductions in the number of leaves by senescence and leaves falling, as observed in citrus (Al-Absi, 2009). Al-Absi (2009) reports that the leaves falling in the three genotypes studied should be proposed as a droughtavoidance mechanism in itself. In the present study, however, leaves were not observed falling during the experimental period, suggesting that the total LA was reduced in part by the lower emission of new leaves, but also to smaller leaves due to reduced cell expansion.

LA is a factor of great importance in physiological studies, mainly to cultivated plants, since it is one of the determinant factors in the crop production. Leaves are the source of assimilates to the shoots as well as to roots, and they provide the structure responsible for nutrient assimilation, playing an important role in plant's growth (Bonfim-Silva et al., 2011). Peixoto et al. (2006) observed reductions of $40 \%$ in the LA after 12 days of withholding water and decreases in LAR after a period of re-watering in citrus genotypes. The authors stated that these reductions occurred due to the tendency of LAR to diminish with the plant growth, since in the initial phase of development most assimilates are converted into leaves aiming at harvesting the solar radiation through photosynthetic processes.

Although photosynthesis was not evaluated in this work, weight gain happens due to carbon assimilation. TDM was not affected by water deficit in the treatments of both genotypes at 75 or $50 \%$ of FC, demonstrating that these levels of water (mild and moderate stresses) did not affect carbon gain in the initial phase of development.

However, in general, 14-CPA had a lower TDM than 13-CPA when compared to the control plants and those at $75 \%$ of $\mathrm{FC}$. In situations of moderate or severe stress, both genotypes showed similar values of TDM (Table 3).

Only plants under $25 \%$ of $\mathrm{FC}$ had reductions in dry matter of leaves and stem in both genotypes (Table 3). However, the roots of 13-CPA grown under 50 and $25 \%$ of FC showed a significant reduction in dry matter compared with control plants, while 14-CPA was not affected. These results demonstrate the physiological differences between the genotypes, in relation to root growth as a response to drought. The roots are in contact with the soil and are the first organ to feel the effects of soil desiccation. The behavior observed in 14-CPA is a xeromorphic characteristic, which could be classified as a droughttolerance mechanism that maintains root growth during drought conditions. At the same time, the fact that both genotypes of Barbados cherry did not reduce by more than $50 \%$ of the TDM demonstrates a certain degree of drought-tolerance.

Similar results were found by Cerqueira et al. (2004) upon analyzing the response of some citrus rootstock to water deficit. The authors verified that the hybrids did not show a reduction in the shoot dry matter with the increase of water stress. Magalhães Filho et al. (2009), while evaluating the water deficit in two orange tree rootstocks, verified reductions in $\mathrm{CO}_{2}$ assimilation rate after 56 days of withholding water. The authors stated that this decrease reflected smaller dry matter accumulation in those plants. In addition, the authors observed different responses to water deficit in lemon genotypes. The dry mass of roots in lemon 'Cravo' was similar for both treatments with and without stress, which is similar to the response found to genotype 14-CPA in the present study, while in lemon 'Trifoliata' RDM was smaller than the control, a similar response to genotype 13-CPA in the current work.

The biomass distribution pattern revealed different physiological behavior in 14-CPA genotype, which increased biomass allocation to the roots and reduced biomass allocation to the leaves. This behavior has been previously reported and is accepted as either drought avoidance or a survival strategy. The root depth helps the plant to survive during times of low-soil water availability. This preferential allocation to the roots indicates an increase in the absorptive area and represents a better way to explore soil moisture and, at the same time, reduces water loss by using a smaller transpiration area. This behavior was confirmed by examining the root: shoot ratio data, which did not occur with 13-CPA. Medeiros et al. (2009) upon submitting six-month-old seedlings of the Barbados cherry to four water irrigation regimes 
observed similar results with genotype 14-CPA. Seedlings under severe water stress (25\% of FC) allocated more photoassimilates to roots than shoots in comparison with control plants $(100 \%$ of $\mathrm{FC})$ after 35 days of stress, modifying the root to shoot ratio.

Water relations are generally directly affected by water deficit, because they reduce the water flow in the soil-plantatmosphere system. $\Psi_{w}$ decreases mainly in times of high evaporative atmospheric demand. Other factors, such as high temperature and low relative humidity, increase the vapor pressure deficit between the leaf and the air, thereby increasing the loss of water by transpiration, which favors the decline of leaf water potential. $\Psi_{\text {wpd }}$ measurement is known to be more sensitive when evaluating water deficit in plants because significant water loss by transpiration is not observed at this time, and the values of $\Psi_{w}$ in soil-plant system tends towards equilibrium. Thus, the predawn evaluation should provide a better demonstration of the water potential in the root zone (Cairo, 1995; Améglio et al., 1999; Sircelj et al., 2005).

However, this equilibrium in the water status is currently being questioned, since some plants present nocturnal transpiration (Bucci et al., 2005), and this loss of water overnight induces imbalance in predawn leaf water potential. In this research, $\Psi_{\text {wpd }}$ was reduced only in plants under severe stress ( $25 \%$ of FC) to 14-CPA, but it was not significant to 13-CPA, although both genotypes showed a tendency to reduce the absolute value overall. Such reduction in $\Psi_{w}$ should be induced by reduction in RWC, which was not affected by a water deficit of $25 \%$ of FC (Figure 4). On the other hand, the accumulation of osmoregulators contributes to reducing $\Psi_{w}$, helping to maintain the water status, but the organic solutes studied here did not accumulate in sufficient amounts to induce alterations in leaf $\Psi_{w}$ to genotype 14-CPA.

Nogueira et al. (2000), while studying two genotypes of the Barbados cherry in the field, observed variations in the $\Psi_{w}$ throughout the day. Similar to these studies, the authors verified the most negative values of water potential at noon in both genotypes, independent of seasonality, although the minimum values occurred in dry season and the genotype UFRPE 8 showed the lowest value (-4.32 MPa). Donato et al. (2006) found values of $\Psi_{\text {wpd }}$ of -1.54 and $-2.08 \mathrm{MPa}$ in citrus submitted to 12 and 16 days without water respectively, while daily-irrigated plants had values of -0.45 and $-0.48 \mathrm{MPa}$ at the same time of evaluation.

RWC was not significantly affected in the present research as a function of water deficit. However, contrasting results were verified by Nogueira et al. (2001) in three-month-old plants of the Barbados cherry which were irrigated and under stress, and propagated by seeds and cutting. The authors observed variations in RWC between the hours of 1000 and 1100 am with the extent of water deficit, reaching $38.4 \%$ in plants propagated by seeds and $48.2 \%$ in those originated by stakes after 20 days without irrigation. This plant response variation, when compared with these studies, could be associated with the lower soil volume used by the authors $(6 \mathrm{~kg})$. Also in the present studies, the plants under severe stress kept receiving $25 \%$ of $F C$, while the soil used by the authors must have been extremely dry, denoting desiccation in those plants, since the stress applied to them was for water suppression.

Compatible organic solute accumulation in response to drought is an important mechanism to maintain cell turgor, contributing to a reduction in the plant water potential (Farooq et al., 2009; Silva et al., 2009b). However, according to Hasegawa et al. (2000), only solute accumulation does not confer complete drought tolerance, but the path that conducts the mechanism of drought tolerance is modulated by this factor.

Silva et al. (2009b), while studying the water relations and organic solute accumulation in six-month-old seedlings of four umbu tree genotypes under intermittent drought, verified reductions in soluble carbohydrates in leaves after 31 days of water stress. In the roots, the authors observed an increase of $7.14 \%$ only in genotype GBU48. According to Pimentel (1999), the increases in soluble carbohydrate content may occur in the beginning of the stress period for two reasons: as a result of the stoppage of growth and by the water deficit intensity because of starch degradation. In the present study, soluble carbohydrates decreased in the leaves and increased in the roots with the extent of the water deficit, suggesting translocation of photoassimilates from leaves to roots as stated by Pimentel (1999) due to the reduction in growth processes.

Free aminoacids were also affected by drought, but the real means of its accumulation during stress periods are still uncertain (Sircelj et al., 2005). Current studies indicate that the main function of aminoacids could be osmotic adjustment. Alterations in free aminoacid content were verified in two apple cultivars under water deficit, increasing more than $40 \%$ in comparison with control plants (Sircelj et al., 2005). Rodrigues et al. (2010) also verified an increase in aminoacids in leaves of six-monthold jack-plants and sugar apple plants when subjected to eight days without water. These increases were about 61 and $66 \%$ respectively. 
The increase in aminoacid content in genotype 13-CPA along with the increase in protein content demonstrates that there was no proteolysis, but instead of that, synthesis in roots as a response to water deficit. On the other hand, in genotype 14-CPA, this solute could not be considered as fundamental to osmotic adjustment because the stress did not induce increases in the roots as observed with other compounds of the same genotype. The results found in these studies are similar to those found by Silva et al. (2009b) in four umbu tree genotypes under intermittent drought, where the authors verified no differences among genotypes and water treatments relative to protein content in leaves, but increases were found in the roots of one genotype (GBU 44).

In addition to the contribution of osmoregulators, proline is widely found in higher plants and generally is accumulated in large amounts during situations of water stress. However, this accumulation was seen only in genotype 13-CPA in the roots, but not in the leaves, while 14-CPA had no changes in leaves or roots from water stress. Genotypic differences relative to proline accumulation during drought periods as found in these studies have been related to several crops. It is accepted that proline has an important and complex role in drought tolerance of plants and the assistance of osmotic adjustment (Kavi Kishor et al., 2005). Therefore, according to Ashraf and Foolad (2007), aside from its role as an osmoregulator, proline also contributes to membrane stabilization and radical oxygen scavenger, preventing plants from being damaged by environmental stresses.

Nogueira et al. (2001) working with the Barbados cherry seedlings subjected to 20 days without water observed alterations in the proline content, recording $38.1 \%$ more proline in stressed plants than in the control ones when propagated by seeds, and $26.4 \%$ more proline in stressed plants than control ones, when originated by stakes, totaling an amount of 18.0 and $10.2 \mathrm{mg} \mathrm{g}^{-1}$ DM, respectively. In these studies, proline accumulation was observed only in the roots and was not close to the amount observed by Nogueira et al. (2001). However, it certainly contributed to maintaining water inflow and thus growth processes dependent on turgor.

Accumulation of organic solutes in the roots, as observed with 13-CPA, increasing carbohydrates, protein, aminoacids and proline, has an important role in maintaining water inflow from the soil. Consequently, it helps the growth and metabolic processes since there is no increase in root growth in this genotype. The increased root growth in 14-CPA allows it to find water at greater depths in the soil. Therefore, the increase in accumulation of organic solutes, with the aim of absorbing water, was not necessary for 14-CPA in this situation.

The results obtained in this study confirm the hypothesis that the Barbados cherry genotypes present different physiological mechanisms to overcome periods of water deficit in the initial phase of development. The water status is kept in genotype 13-CPA through the accumulation of soluble organic solutes, such as aminoacids, protein, carbohydrates and proline in the roots, which help to maintain the inflow of water from the soil to the plant. The mechanisms used by genotype 14-CPA to avoid desiccation are relative to changes in growth patterns, modifying root to shoot ratio, and the reduction in LA seems to assist the tolerance for periods of water deficit.

Despite the mechanisms used by the genotypes, moderate stress does not induce morphophysiological changes in the Barbados cherry. This demonstrates a drought-tolerance in such species in its initial phase of development.

\section{Acknowledgments}

The authors would like to thank the Conselho Nacional de Desenvolvimento Científico e Tecnológico (CNPq) for their financial support, and colleagues Danúbia Ramos (biologist), Marcelo Ribeiro (agronomist), and graduation student Natália Vaz for their technical support during the experiment.

\section{REFERENCES}

Al-Absi KM (2009) Gas Exchange, Chlorophyll and Growth Response of Three Orange Genotypes (Citrus sinensis [L.] Osbeck) to Abscisic Acid under Progressive Water Deficit. Jordan J. Agric. Sci. 5:421-433.

Améglio T, Archer P, Cohen M, Valancogne C, Daudet FA, Dayau S, Cruiziat $P$ (1999) Significance and limits in the use of predawn leaf water potential for tree irrigation. Plant Soil 207:155-167.

Ashraf M, Foolad MR (2007) Roles of glycine betaine and proline in improving plant abiotic stress resistance. Environ. Exp. Bot. 59:206-216.

Bates LS (1973) Rapid determination of free proline for water-stress studies. Plant Soil 39:205-207.

Benincasa MMP (2003). Análise de crescimento de plantas (noções básicas). FUNEP, Jaboticabal.

Bonfim-Silva EM, Silva TJA, Cabral CEA, Kroth BE, Rezende D (2011) Desenvolvimento inicial de gramíneas submetidas ao estresse hídrico. Rev. Caatinga 24:180-186.

Bradford MM (1976) A rapid and sensitive method for the quantitation of microgram quantities of protein utilizing the principle of protein-dye binding. Anal. Biochem. 72:248-250. 
Bucci SJ, Goldstein G, Meinzer FC, Franco AC, Campanello P, Scholz FG (2005) Mechanisms contributing to seasonal homeostasis of minimum leaf water potential and predawn disequilibrium between soil and plant water potential in Neotropical savanna trees. Trees 19:296-304.

Cairo PAR (1995) Curso básico de relações hídricas de plantas. UESB, Vitória da Conquista.

Cerqueira EC, Castro Neto MT, Peixoto CP, Soares Filho WS, Ledo CAS, Oliveira JG (2004) Response of citrus rootstocks to water deficit. Rev. Bras. Frutic. 26:515-519.

Chaves MM, Maroco JP, Pereira, JS (2003) Understanding plant responses to drought - from genes to the whole plant. Funct. Plant Biol. 30:239-264.

Donato SLR, Pereira CS, Barros ZJ, Siqueira DL, Salomão LCC (2007) Respostas de combinações de variedades copa e porta-enxerto de citros à deficiência hídrica. Pesq. Agropec. Bras. 42:1507-1510.

Dubois M, Gilles KA, Hamilton JK, Rebers PA, Smith F (1956) Colorimetric method for determination of sugars and related substances. Anal. Chem. 28:350-356.

Farooq M, Wahid A, Kobayashi N, Fujita D, Basra SMA (2009) Plant drought stress: effects, mechanisms and management. Agron. Sustain. Dev. 29:185-212.

Hasegawa PM, Bressan RA, Zhu Jian-Kang, Bohnert HJ (2000) Plant cellular and molecular responses to high salinity. Annu. Rev. Plant Physiol Plant Mol. Biol. 51:463-599.

Kavi Kishor PB, Sangam S, Amrutha RN, Sri Laxmi P, Naidu KR, Rao KRSS, Sreenath Rao Reddy KJ, Theriappan P, Sreenivasulu N (2005) Regulation of proline biosynthesis, degradation, uptake and transport in higher plants: Its implications in plant growth and abiotic stress tolerance. Curr. Sci. 88:424-438.

Larcher W (2006) Ecofisiologia vegetal. Translation: Prado CHBA. Rima, São Carlos.

Magalhães Filho JR, Amaral LR, Machado DFSP, Medina CL, Machado EC (2008) Water deficit, gas exchange and root growth in 'Valencia' orange tree budded on two rootstocks. Bragantia 67:75-82.

Mascarenhas JC, Beltrão BA, Souza Junior LC, Galvão MJTG, Pereira SN, Miranda JLF (2005) Projeto cadastro de fontes de abastecimento por água subterrânea. Diagnóstico do município de Carpina, Estado de Pernambuco. Recife: CPRM/PRODEEM, 21p. [cited 2012 Jun 06]. Available: at: http://www.cprm.gov.br/rehi/atlas/pernambuco/relatorios/ CARP042.pdf.

Marchese JA, Ferreira JFS, Rehder VLG, Rodrigues 0 (2010) Water deficit effect on the accumulation of biomass and artemisinin in annual wormwood (Artemisia annua L., Asteraceae). Braz. J. Plant Physiol. 22:1-9.

Medeiros DB, Pacheco CM, Lima DRM, Silva NV, Ribeiro MS, Silva EC, Nogueira RJMC (2009) Produção de fitomassa, alocação de fotossintatos, área foliar e pigmentos fotossintéticos em acerola sob deficiência hídrica. In: Proceedings of the XII Congresso Brasileiro de Fisiologia Vegetal (XII CBFV). Fortaleza, Brazil, p. 238.

Mielke MS, Hoffmann A, Endres L, Fachinello JC (1995) Comparison of laboratory and field methods for the estimation of leaf area of wild fruit species. Sci. Agri. 52:82-88.

Musser RS, Lemos MA, Lima VLAG, Mélo EA, Lederman EL, Santos VF (2005) Physical and production characteristics of acerola fruit from active germplasm bank in Pernambuco. Rev. Bras. Frutic. 27:320-323.
Nascimento AKS, Fernandes PD, Suassuna JF, Sousa MSS, Oliveira ACM (2010) Porta enxerto de citros sob estresse hídrico. Rev. Bras. Agric Irrigada. 4:99-103.

Nogueira RJMC, Moraes JAPV, Burity HA (2000) Curso diário e sazonal das troas gasosas e do potencial hídrico foliar em aceroleiras. Pesq. Agropec. Bras. 35:1331-1342.

Nogueira RJMC, Moraes JAPV, Burity HA, Bezerra Neto E (2001) Modifications in vapor diffusion resistence of leaves and water relations in barbados cherry plants under water stress. Braz. J. Plant Physiol. 13:75-87.

Peixoto CP, Cerqueira EC, Soares Filho WS, Castro Neto MT, Ledo CAS, Matos FS, Oliveira JG (2006) Growth analysis of different citrus genotypes cultivated under water deficit. Rev. Bras. Frutic. 28:439-443.

Pimentel C (1999) Relações hídricas em dois híbridos de milho sob dois ciclos de deficiência hídrica. Pesq. Agropec. Bras. 34:2021-2027.

Rodrigues BM, Souza BD, Nogueira RM, Santos MG (2010) Tolerance to water deficit in young trees of jackfruit and sugar apple. Rev. Cienc. Agron. 41:245-252.

Santesteban LG, Mirandaa C, Royoa JB (2009) Effect of water deficit and rewatering on leaf gas exchange and transpiration decline of excised leaves of four grapevine (Vitis vinifera L.) cultivars. Sci. Hort. 121: 434-439.

Scholander PF, Hammel HT, Hemingsen EA, Bradstreet ED (1964) Hydrostatic pressure and osmotic potentials in leaves of mangroves and some other plants. Proc. Natl. Acad. Sci. USA 52:119-125.

Shao HB, Chen XY, Chu LY, Zhao XN, Wu G, Yuan YB, Zhao CX, Hu ZM (2006) Investigation on the relationship of proline with wheat anti-drought under soil water deficits. Coll. Surf. B Biointerf. 53:113-119.

Shao HB, Chu LY, Jaleel CA, Zhao CX (2008) Water-deficit stress induced anatomical changes in higher plants. CR Biol. 331:215-225.

Silva EC, Nogueira RJMC, Vale FHA, Araujo FP, Pimenta MA (2009a) Stomatal changes induced by intermittent drought in four umbu tree genotypes. Braz. J. Plant Physiol. 21:33-42.

Silva EC, Nogueira RJMC, Vale FHA, Melo NF, Araujo FP (2009b) Water relations and organic solutes production in four umbu tree (Spondias tuberosa) genotypes under intermittent drought. Braz. J. Plant Physiol. 21:43-53.

Silva EC, Silva MFA, Nogueira RJMC, Albuquerque MB (2010) Growth evaluation and water relations of Erythrina velutina seedlings in response to drought stress. Braz. J. Plant Physiol. 22:225-233.

Sircelj H, Tausz M, Grill D, Batic F (2005) Biochemical responses in leaves of two apple tree cultivars subjected to progressing drought. J. Plant Physiol. 162:1308-1318.

Souza CC, Oliveira FA, Silva IF, Amorim Neto MS (2000) Evaluation of methods of available water determinaton and irrigation management in "terra roxa" under cotton crop. Rev. Bras. Eng. Agric. Ambiental. 4:338-342.

Toumi I, Gargouri M, Nouairi I, Moschou PN, Bem Salem-Fnayou A, Mliki A, Zarrouk I, Ghorbel A (2008) Water stress induced changes in the leaf lipid composition of four grapevine genotypes with different drought tolerance. Biol. Plantarum 52:161-164.

White DA, Turner NC, Galbraith JH (2000) Leaf water relations and stomatal behavior of four allopatric Eucalyptus species planted in Mediterranean southwestern Australia. Tree Physiol. 20:1157-1165.

Yemm EW, Cocking EC (1955) The determination of aminoacids by ninhydrin. Analyst 80:209-213. 